\title{
Partisipasi Masyarakat Dalam Pembangunan Desa Bendung Air Timur
}

\author{
${ }^{1}$ Efnika Septia, ${ }^{2}$ Pebriyenni \\ ${ }^{12}$ Program Studi Pendidikan Pancasila dan Kewarganegaraan, Fakultas Keguruan dan Ilmu \\ Pendidikan, Universitas Bung Hatta \\ Sumatera Barat,Indonesia \\ Email : efnikaseptiappkn@gmail.com
}

\begin{abstract}
This article aims to find out how the level of public participation in the decision-making process in the Bendung Air Timur village development program. The method used is a descriptive method. 60 respondents were taken randomly as many as 238 households in the East Air Dam village. Data collection uses questionnaires / questionnaires and is assisted by interview techniques. The analysis technique used is descriptive analysis (frequency distribution analysis and percentage). The results of the study show: (1) In terms of the indicators used, most of the respondents had never participated in the decision-making process of development programs in the village/village; (2) In terms of the indicators used, most of the respondents had never participated in the implementation of development programs in the villages / villages. Based on the results of the research conclusions: (1) Public participation in the East Air Dam village in the decision making process for village/village development programs is generally low; (2) Public participation in the East Air Dam Village / Village in the process of implementing / implementing development programs, generally villages / villages are low.
\end{abstract}

Keywords: community; participation; rural development

\begin{abstract}
Abstrak
Artikel ini bertujuan untuk mengetahui bagaimana tingkat partisipasi publik dalam proses pengambilan keputusan dalam program pembangunan desa Bendung Air timur. Metode yang digunakan adalah metode deskriptif. Responden sebanyak 60 kepala keluarga diambil secara acak (random) sebanyak 238 rumah tangga didesa Bendung Air Timur. Pengumpulan data menggunakan kuesioner / kuesioner dan dibantu dengan teknik wawancara. Teknik analisis yang digunakan adalah analisis deskriptif (analisis distribusi frekuensi dan persentase). Hasil penelitian menunjukkan: (1) Dari segi indikator yang digunakan ternyata sebagian besar responden belum pernah berpartisipasi dalam proses pengambilan keputusan program pembangunan di desa / desa; (2) Dari segi indikator yang digunakan ternyata sebagian besar responden belum pernah berpartisipasi dalam pelaksanaan program pembangunan di pedesaan / desa. Berdasarkan hasil kesimpulan penelitian: (1) Partisipasi publik desa Bendung Air Timur dalam proses pengambilan keputusan untuk program pembangunan desa / desa umumnya rendah; (2) Partisipasi publik Desa / Desa Bendung Air Timur dalam proses pelaksanaan / pelaksanaan program pembangunan, umumnya desa / desa rendah.
\end{abstract}

Kata Kunci : Masyarakat; partisipasi; pembangunan pedesaan

Link DOI : http://dx.doi.org/10.31314/pjia.7.2.129-135.2018 


\section{PENDAHULUAN}

Keberhasilan suatu proses pembangunan tidak dapat dilepaskan dari adanya partisipasi anggota masyrakatnya, baik sebagai kesatuan sistem maupun sebagai individu yang merupakan bagi yang sangat integral yang sangat penting dalam proses dinamika pembangunan, karena secara prinsip pembangunan ditunjukkan guna mewujudkan masyarakat yang sejahtera. Oleh sebab itu tanggung jawab berhasil tidaknya pembangunan tidak saja ditangan pemerintah tetapi juga ditangan masyarakat. Kesadaran dan partisipasi aktif dari masyarakat merupakan salah satu kunci keberhasilan pembangunan, dalam hal ini mencapai target pembangunan perlu ditunjukkan oleh kebijaksanaan pemerintah (Akbar, MF, Suprapto, Surati, 2018)

$$
\text { Pada hakikatnya tujuan }
$$

pembangunan suatu Negara dilaksanakan adalah untuk mensejahterakan masyarakat, demikian dengan halnya Negara Indonesia. Dalam pembukaan Undang-undang Dasar 1945 dinyatakan bahwa tujuan Pembangunan Nasional Bangsa Indonesia adalah melindungi segenap bangsa dan seluruh tumpah darah Indonesia, memajukan kesejahreaan umum, mencerdaskan kehidupan bangsa, serta ikut melaksanakan ketertiban dunia. Untuk mewujudkan tujuan tersebut dilaksankan pembangunan nasional, yaitu pembangunan manusia Indonesia seutuhnya dan pembangunan masyarakat seluruhnya( Ginanjar, 2006).

Pembangunan adalah sesuatu yang dari, oleh, dan untuk masyarakat. Sehingga pembangunan bukanlah kegiatan yang direncanakan, dilaksanakan dan dimaksudkan untuk memenuhi kepentingan segolongan atau sekelompok warga masyarakat. Pembangunan merupakan suatu proses pembaharuan yang continue dan terus menerus dari suatu keadaan tertentu kepada suatu keadaan yang dianggap lebih baik (Ferdi S. Gani, dkk, 2015).

$$
\text { Partisipasi masyarakat dalam }
$$
pembangunan juga persyaratan utama yang akan melandasi keberhasilan dalam proses pembangunan Indonesia. Partisipasi masyarakat dalam pembangunan merupakan kerjasama yang erat antara perencana dan rakyat dalam merencanakan, melaksanakan, melestarikan dan mengembangkan hasil pembangunan yang telah dicapai (Olly Ersy Laoh, dkk, 2015).

Berdasarkan kenyataan dalam pelaksanaan pembangunan desa selama ini menunjukkan bahwa inisiatif dan partisipasi masyarakat desa dalam pembangunan Desa seringkali tidak terwujud sebagaimana yang diharapkan. Hal tersebut ada hubungannya dengan kelemahan-kelemahan dan kekurangan pada masyarakat desa itu sendiri seperti kemiskinan, kurangnya pendidikan, pola pikir yang lemah dan seringkali masih terikat pada tradisi lama, mentalitas yang lemah, dan lain-lain.

Berbagai kelemahan dan kekurangan pada masyarakat desa seperti yang di sebut diatas masih dialami oleh sebagian besar masyarakat Desa Bendung Air Timur, Kecamatan Kayu Aro, Kabupaten Kerinci. Desa Bendung Air Timur berpenduduk 666 jiwa, dimana sebagian besar dari penduduk adalah sebagai petani yang masih hidup dalam 
kemiskinan dan keterbatasan baik dilihat dari segi ekonomi/pendapatan maupun dari segi pendidikan dan pola berpikir. Kondisi seperti ini dapat mempengaruhi tingkat partisipasi dalam pembangunan di desa Bendung Air Timur, baik dalam perencanaan, pelaksanaan, evaluasi atau penilaian, dan pemanfaatan hasil-hasil pembangunan desa itu sendiri.

Tujuan dalam penelitian ini untuk mengetahui tingkat partisipasi masyarakat Desa Bendung Air Timur dalam proses pengambilan keputusan program pembangunan didesa Bendung Air Timur dan juga untuk mengetahui tingkat partisipasi masyarakat Desa Bendung Air Timur dalam proses implementasi program pembangunan di Desa Bendung Air Timur.

\section{METODE PENELITIAN}

Pendekatan penelitian yang digunakan untuk menjawab penelitian ini adalah metode penelitian deskripstif dengan analisa kualitatif. Penelitian deskriptif sebagai penelitian yang berusaha untuk menuturkan pemecahan masalah yang ada sekarang berdasarkan data-data, jadi ia juga menyajikan data, menganalisis dan menginterprestasi, ia juga bisa bersifat komperatif dan korelatif.

Jenis penelitian ini adalah kualitatif deskriptif yang pada akhirnya akan memberikan gambaran faktual mengenai Partisipasi Masyarakat dalam Pembangunan di Desa Bendung Air Timur.

Penelitian ini dilaksanakan di Desa Bendung Air Timur Kecamatan Kayu Aro, Kabupaten Kerinci. Peneliti memilih tempat penelitian ini karena lokasinya adalah tempat tinggal penulis.

Variabel/fokus penelitian yang diamati dalam penelitian ini ialah peranan partisipasi masyarakat dalam pelaksanaan pembangunan desa. Yang dimaksud dengan partisipasi masyarakat dalam pembangunan desa disini ialah keikutsertaan masyarakat dalam tahapantahapan pembangunan didesa Bendug Air Timur, baik program pembangunan yang ditetapkan dan dilaksanakan oleh masyarakat desa sendiri maupun program pembangunan yang data dari pemerintah atas desa. Sub-variabel dalam penelitian ini, yaitu : (1) partisipasi masyarakat dalam pengambilan keputusan program pembangunan desa; (2) partisipasi masyarakat dalam proses implementasi program pembangunan desa.

Populasi dalam penelitian ini ialah semua warga masyarakat Desa Bendung Air Timur, Kecamatan Kayu Aro, Kabupaten Kerinci. sesuai data jumlah kepala keluarga di Desa Bendung Air Timur ialah sebanyak 238 kepala keluarga.

Sampel responden penelitian diambil dari para kepala keluarga dengan teknik proporsional random sampling atau pengambilan sampel secara acak. Dalam hal ini sampel responden diambil sebesar 25\% dari jumlah kepala keluarga yaitu sebanyak 60 orang. Untuk mendapat data yang diperlukan dalam penelitian ini maka digunakan instrumen dan teknik pengumpulan data sebagai berikut:

1. Kuesioner / angket

2. Observasi 
Teknik analisis data yang digunakan dalam penelitian ini ialah analisis deskriptif (Arikunto, 2000) dengan prosedur analisis sebagai berikut: 1). Penilaian data dan tabulasi data. Penilaian dan tabulasi data dilakukan dengan memberikan nilai angka (score) terhadap jawaban-jawaban responden pada setiap pertanyaan pada kuesioner/angket.

2). Pengolahan dan analisis data, dilakukan dengan menggunakan analisis statistik deskriptif yaitu analisis tabel frekuensi dan persentase. Perhitungan persentase adalah dengan rumus sebagai berikut :

$$
\mathrm{p}=\mathrm{f} / \mathrm{n} \times 100 \%
$$

dimana : dicari;

$$
\mathrm{p}=\text { nilai persentase yang }
$$

$\mathrm{f}=$ frekuensi, yaitu banyaknya nilai pada setiap kategori data;

$$
\mathrm{n} \text { = sampel, yaitu total }
$$
data sampel.

3). Interpretasi hasil analisis data, yaitu menterjemahkan dan menjelaskan hasil analisis data dengan kalimat yang bersifat kualitatif.

\section{HASIL DAN PEMBAHASAN}

Sebagaimana disebutkan dalam dalam uraian pendahuluan bahwa tujuan dari penelitian ini adalah (1) untuk mengetahu tingkat partisipasi masyarakat desa bendung air timur dalam proses pengambilna keputusan program pembangunan di desa, dan (2) untuk mengetahui tingkat partisipasi masyarakat desa bendung air timur dalam proses implementasi/pelaksanaan program pembangunan di desa.

Sehubungan dengan tujuan penelitian tersebut maka dilakukan penelitian terhadap sebanyak 60 orang kepala keluarga yang diambil dengan teknik ramdom sampling (acak) dari 238 KK yang ada didesa bendung air timur.

Pengumpulan data menggunakan kuesioner (angket) dan dibantu dengan teknik wawancara. Hasil penelitian ditabulasi dan dianalisis dengan teknik analisis distribusi frekuensi dan persntase. Hasil analisis data di kemukakan secara berturut sebagai berikut :

\section{Partisipasi masyarakat dalam} proses pengambilan keputusan pembangunan Desa

Sebagaimana yang telah dikemukakan dalam perumusan/defenisioperasional variabel penelitian pada metode penelitian bahwa yang di maksud dengan partisipasi dalam proses pengambilan keputusan disini aialah keikutsertaan atau peran serta masyarakat desa bendung air timur dalam proses penyusunan atau penetapan rencana program-program pembangunan desa tersebut dilihat dari beberapa indikator yaitu : mengikuti atau menghadiri acara pertemuan atau rapatrapat di desa yang membicarakan penetapan rencana program-program pembangunan di desa yang diadakan oleh pemerintah desa/BPD/LPM; Ikutserta aktif dalam pembicaraan atau diskusi pada acara pertemuan/rapat perencanaan pembangunan didesa/kampung yang diadakan oleh Pemerintah Desa dan 
BPD/LPM; Ikutserta menyampaikan informasi kepada pemerintah desa atau BPD/MTT dan LPM tentang permasalahan pembangunan di desa yang diperlukan untuk penyusunan rencana program pembangunan desa; Ikutserta dalam menyampaikan usul/saran/pendapat kepada pemerintah desa/BPD/LPM dalam rangka penyusunan perencanaan program pembangunan desa; Ikutserta dalam menyampaikan suatu kritikan kepada pemerintah desa/BPD/LPM yang berkenaan dengan penyusunan rencana program pembangunan desa; Ikutserta dalam permufakatan pengambilan suatu keputusan rencana program pembangunan desa yang akan ditetapkan oleh pemerintah desa; Ikutserta menyampaikan penolakan atau ketidak setujuan terhadap rencana program pembangunan desa yang ditetapkan oleh pemerintah desa/BPD/LPM.

Indikator partisipasi masyarakat dalam proses pengambilan keputusan program pembangunan desa tersebut selanjutnya dijabarkan kedalam 7 (tujuh) item pertanyaan/koesioner yang diajukan kepada responden. Setiap pertanyaan disediakan tiga jawaban yang menunjukkan tingkat partisipasi atau keikutsertakaan mereka dalam kegiatan yang terkait dengan proses pengambilan keputusan program pembangunan di desa bendung air timur, yaitu : sering, kadangkadang, tidak pernah.

\section{Partisipasi Masyarakat dalam Proses Implementasi Program Pembangunan Desa.}

Partisipasi masyarakat dalam proses implementasi program pembangunan didefenisikan secara operasioanal sebagai tingkat keikutsertaan atau peranserta masyarakat desa bendung air timur, kecamatan kayu aro, kabupaten kerinci dalam proses pelaksanaan program-program pembangunanyag sudah ditetapkan di desa bendung air timur.

Partisipasi dalam implementasi program pembangunan desa tersebut diamati atau diukur melalui beberapa indicator yaitu: Ikutserta dalam memberikan sumbangan pemikiran (saran/pendapat) untuk pelaksanaan suatu program pembangunan di desa bendung air timur yang sudah ditetapkan di putuskan bersama; Ikutserta dalam kegiatan gotong royong dalam pelaksanaan program pembangunan di desa; Ikutsertadalam memberikan bantuan tenaga atau sbagai tenaga kerja dalam pelaksanaan program pembangunan di desa sebagi tenaga kerja,tenaga administrasi; Ikutserta menjadi anggota panitia pelaksana dari pelaksanaan program pembangunan di desa yang sudah ditetapkan dan diputuskan bersama; ikutserta memberikan sumbangan bantuan uang tunai (sesuai kemampuan) untuk pelaksanaan suatu program pembangunan di desa yang sudah ditetapkan/diputuskan bersama; Ikutserta memberikan bantuan bahan ( sesuai kemampuan) untuk pelaksaan suatu program pembangunan didesa yang sudah ditetapkan/diputuskan bersama; Ikutserta memberikan bantuan atau meminjamkan peralatan kerja untuk mendukung pelaksanaan suatu program pembangunan didesa yang sudah ditetapkan/diputuskan bersama; ikutserta dalam kegiatan organisasi atau 
kelompok-kelompok

sosial

kemasyarakatan/keagamaan

yang

menunjang kegiatan pembangunan didesa.

Bersama indikator pengukuran partisipasi masyarakat dalam proses implementasi program pembangunan desa tersebut, disusun sebanyak 8 item pertanyaan yang diajukan kepada sebanyak 60 orang responden yang terpilih. Tingkat prtisipasi masyarakat desa dalam implementasi program pembangunan desa tersebut juga dinilai dalam 3 kategori, yaitu: sering berpartisipasi, kadang-kadang berpartisipasi, tidak pernah berpartisipasi.

\section{PENUTUP}

\section{Kesimpulan}

Berdasarkan hasil penelitian yang dilakukan ditarik kesimpulan sebagai berikut, bahwa Partipasi masyarakat desa Bendung Air Timur di dalam proses pengambilan keputusan program pembangunan di desa bendung air timur umumnya masih rendah dilihat dari indikator yang digunakan yaitu : keikutsertaan dalam acara pertemuan atau rapat-rapat di desa yang membicarakan penetepan rencana program-program pembangunan didesa Bendung Air Timur yang diadakan oleh pemerintah desa/BPD/LPM; keikutsertaan dalam pembicaraan atau diskusi pada acara pertemuan/rapat perencanaan pembangunan didesa bendung air timur yang diadakan oleh Pemerintah Desa dan BPD/LPM; Selanjutnya partisipasi masyarakat dalam proses implementasi/pelaksanaan program - program pembangunan Desa Bendung Air Timur, juga umumnya masih rendah dilihat dari indikator yang digunakan yaitu : keikutsertaan dalam memberikan sumbangan pemikiran (saran/pendapat), keikutsertaan dalam memberikan bantuan tenaga atau sebagai tenaga kerja dalam pelaksanaan program pembangunan di desa seperti sebagai tenaga kerja, sebagai tenaga administrasi

\section{Saran}

Bertolak belakang dari hasil penelitian tersebut maka perlu direkomendasikan saran sebagai berikut : Diperlukan upaya yang lebih efektif untuk meningkatkan partisipasi masyarakat Desa Bendung Air Timur didalam proses pengambilan keputusan program; Pembangunan desa, antara lain seperti : memberikan penerangan atau penyuluhan atau motivasi kepada masyarakat, mengoptimalkan peran lembaga kemasyarakatan ( LPM,PKK,dan BPD/MTT) dalam pembangunan di desa bendung air timur, meningkatkan peran organisasi-organisasi sosial kemasyarkatan/ keagamaan dalam menggerakkan pertisipasi masyrakat, dan mengoptimalkan pelaksanaan demokrasi di dalam penyusunan program pembangunan didesa Bendung Air Timur; Partisipasi masyarakat Desa Bendung Air Timur didalam proses implementasi atau pelaksanaan programprogram pembangunan desa juga perlu ditingkatkan 


\section{DAFTAR PUSTAKA}

Akbar, M. F., Suprapto, S., \& Surati, S. (2018). Partisipasi Masyarakat Dalam Perencanaan Pembangunan di Desa Jatimulya Kabupaten Boalemo. Publik (Jurnal Ilmu Administrasi), 6(2), 135-142.

Arikunto, Suharsimi. (2000) Prosedur Penelitian : Suatu Pendekatan Praktik, Edisi Revisi VI, Jakarta : PT Rineka Cipta, 2006.

Kartasamit, Ginanjar, (2006). Pembangunan Untuk Rakyat. Jakarta: PT. Pustaka.

Gani, F. S. (2015). Tahapan Partisipasi Masyarakat Dalam Program Pembangunan Infrastruktur Perdesaan (PPIP) Di Desa Dungaliyo Kecamatan Dungaliyo Kabupaten Gorontalo. Jurnal Ilmiah Ilmu Administrasi Publik, 5(1), 919.

Melis, Abd. Azil Muthalib, Apado. (2016). Analisis Partisipasi Masyarakat Dalam Pembangunan. Jurnal Ekonomi, 1(1), 2503-1937.

Teraik Kogoya, Benu Olfie, Olly Esry Laoh. (2015). Partisipasi Masyarakat Terhadap Pembangunan Infrastruktur Jalan Desa di Kabupaten Lanny JayaPapua. Jurnal Berkala Ilmiah Efisiensi, 15 (2).

Peraturan Desa Bendung Air Timur Nomor. 01 Tahun 2016. Tentang Rencana Pembangunan Jangka Menengah Desa. 